\title{
Using design thinking to cultivate the next generation of female STEAM thinkers
}

\author{
Rie Kijima ${ }^{1 *}$ (D), Mariko Yang-Yoshihara ${ }^{2}$ and Marcos Sadao Maekawa ${ }^{3}$
}

\begin{abstract}
Background: Countries around the world have struggled to implement education policies and practices to encourage more female youths to pursue Science, Technology, Engineering, and Mathematics (STEM). This has resulted in a persistent and sizeable gender gap in science and mathematics subjects in some countries. Using mixed-methods sequential explanatory design, this paper explores an educational intervention-specifically, a 3-day design thinking workshop-in Japan, designed to change female youths' perceptions regarding STEM topics. Framed using a constructivist approach to learning, the workshops aimed to engender creative confidence, empathy, and global competence among youths.

Results: The findings show that female youths who participated in the workshop had increased interest in engineering, greater creative confidence, more positive perceptions of STEM, higher levels of empathy and prosocial factors, and a more varied outlook on career options. We argue that this short intervention had a strong influence on the female youths' mindsets, self-images, and perceptions of STEM.

Conclusion: This study provides empirical support that a short intervention can produce positive change in how female youths relate to STEM. In gendered societies, an innovative method like design thinking has the potential to revitalize education curriculum in ways that spur female youths' confidence and creativity, enabling them to imagine a career in the field of STEM.
\end{abstract}

Keywords: Design thinking, STEM, STEAM, Creative confidence, Empathy, Female youths

\section{Introduction}

Countries around the world have struggled to implement education policies to level the playing field for all genders to pursue their interest in Science, Technology, Engineering, and Mathematics (STEM) fields. Gender inequality in STEM fields continues to persist at various levels, as evidenced by mathematics scores in secondary education (Guiso, Monte, Sapienza, \& Zingales, 2008), employment in math-intensive fields such as engineering (Ceci, Williams, \& Barnett, 2009), and the gender wage gap in STEM professions (Blau \& Kahn, 2017). Gender gaps in STEM start well before women enter the workforce. Students begin forming strong academic

\footnotetext{
* Correspondence: rie.kijima@utoronto.ca

'Munk School of Global Affairs and Public Policy, University of Toronto, 1 Devonshire Place, Toronto, ON M5S 3K7, Canada

Full list of author information is available at the end of the article
}

preferences and particular likes and dislikes of certain subjects in middle school (Fryer Jr \& Levitt, 2010). It is around this phase in their adolescent years that girls become less motivated to pursue STEM topics (Kerr \& Kurpius, 2004). Also, unless they take advanced levels of mathematics in high school, it is unlikely that girls will pursue science, mathematics, or engineering degrees in college (Mcllwee \& Robinson, 1992).

This study is at the intersection of two approaches to STEM education. The first is the traditional focus on STEM as a framework of learning that emphasizes knowledge acquisition, such as theory to model-based reasoning, which involves an iterative process of analyzing data to support or advance a theory (e.g., Borko, 2016; Duschl \& Bismack, 2016). The second is STEAM, an approach that adds the Arts (hence the "A") to STEM in order to harness a sense of creativity and inquiry to 
conventional STEM education (e.g., Daugherty, 2013). Our research emphasizes the importance of STEAM learning and how design thinking complements STEM. Proponents of STEAM argue that integrating artistic and design approaches will spur innovation (Madden et al., 2013; Robelen, 2011; Sousa \& Pilecki, 2013). Furthermore, the integration of art and design into STEM allows for more human-centered innovation, ensuring that technological development is responsive to the needs, desires, and challenges of users (Chen \& Lo, 2019).

This study explores what benefits an educational program that utilizes design thinking might have for a specific group of learners. Our study is significant because it contributes to our understanding of how an immersive design thinking educational program can foster greater interest in STEM among female adolescents. Moreover, it addresses the need to understand how design thinking could serve as "a model of thinking" for learners in the twenty-first century (Li et al., 2019a, p. 94). This study is also relevant because it highlights how a human-centric, empathy-focused pedagogical approach encourages youths to become more actively engaged with issues around them.

The study's main research question asks: What kind of changes in terms of perception and understanding of STEM do we observe among youths who participate in the 3-day design thinking workshop? Specifically, we hypothesized that the intervention would increase the female youths' interest and motivation and provide them the nudge needed to consider STEM as plausible and interesting fields of study. We offer evidence regarding the influence of the workshop by analyzing student-level data collected between 2016 and 2020 via surveys and interviews. We find that female youths who participated in the workshop showed increased interest in engineering and design, greater creative confidence, more positive perceptions of STEM, higher levels of empathy and pro-social factors, and a more varied outlook on career options. We end by proposing a model for an integrated approach to STEM learning within formal classroom settings and beyond (English \& King, 2015; Estapa \& Tank, 2017).

\section{Background}

Globally, studies have shown that there is almost no difference between boys and girls in their aptitude and performance in mathematics in the early years of elementary school, but the gender gap widens over time. By fifth-grade, female students in the USA score 0.2 standard deviations lower than their male cohorts, which is equivalent to approximately 2.5 months of instruction (Fryer Jr \& Levitt, 2010). A cross-national study of 19 African countries yields similar results: boys outperform girls in mathematics and the factors associated with this gender gap are due to socio-cultural factors, such as high fertility rate, mother's educational level, and greater prevalence of Islam (Dickerson, McIntosh, \& Valente, 2015). Japan follows this global trend. There is no statistically significant difference between boys and girls in their performance in mathematics in fourth grade since 2003; however, the gender gap widens over time (Meinck \& Brese, 2019). By the time students reach eighth grade mathematics, there is a gender gap in favor of boys. This finding is consistent over a period of 20 years (Meinck \& Brese, 2019, p. 8).

Japan represents a perfect example of a narrow and leaky pipeline. There is a very small percentage of students entering STEM fields and the retention rate of STEM majors is extremely low. Nationally, women's representation in higher education is below parity. In 2017, female students comprised $36.9 \%$ of undergraduates, $28.9 \%$ of doctoral students, and $26.7 \%$ of Master's students. ${ }^{1}$ Furthermore, women make up $16.2 \%$ of the total number of researchers in Japan, which puts Japan at the bottom of 25 advanced economies (The Cabinet Office, 2019). ${ }^{2}$ In STEM fields, women accounted for $8.8 \%$, $14.6 \%$, and $15.9 \%$ of all researchers in engineering, science, and natural science, respectively (The Cabinet Office, 2018).

Underrepresentation of women in Japanese higher education is particularly notable in STEM fields. In academia, women made up $7.4 \%$ and $4.9 \%$ of faculty in science and engineering fields, respectively, compared to 22.9\% in humanities (The Cabinet Office, 2016, p. 372). Certain areas in STEM fields suffer particularly low representation of women in STEM fields: Mechanical Engineering (1.6\%), Applied Chemistry (3.6\%), Electrical Engineering (3.7\%), Physics (4.4\%), and Civil Engineering (5.7\%) in 2007 (Kato \& Chayama, 2012, p. 37).

Increasing various pathways to pursue STEM promises to yield benefits for women. In particular, encouraging women to pursue and excel within STEM fields could potentially increase women's private rate of return-a consideration that is particularly relevant in the case of Japan. Today, the difference between the male and female median wage in Japan is 23.5, approximately 10.6 percentage points higher than the OECD average, indicating a large gender wage gap in favor of men (OECD,

\footnotetext{
${ }^{1}$ It is noteworthy that these numbers were even lower just a decade ago. In 2007, the share of female students in Science was $25.3 \%$ at the undergraduate level, $17.5 \%$ at the doctoral level, and $22.1 \%$ at the Master's level.

${ }^{2}$ Proportion of Women Researchers, in descending order of countries (The Cabinet Office, 2019): Iceland, Portugal, Estonia, Slovak Republic, Spain, Greece, Norway, UK, Poland, Turkey, Slovenia, Italy, Denmark, US, Belgium, Sweden, Chile, Switzerland, Ireland, Finland, Hungary, Austria, Germany, Luxembourg, Czech Republic, Netherlands, Korea, and Japan.
} 
2020). According to data from Europe, it is estimated that women who pursue STEM careers earn, on average, $33 \%$ more than women who pursue non-STEM careers (Beede et al., 2011). Some studies also show a narrower gender pay gap in STEM than in non-STEM professions (Beede et al., 2011, p. 1), especially among women and underrepresented minorities (Oh \& Lewis, 2011). If this condition also holds true in Japan, women who pursue STEM could expect a higher private rate of return.

\section{Conceptual framework}

We draw our conceptual framework from the social constructivist approach to learning. Constructivists such as Jean Piaget and Lev Vygotsky argue that learners construct their own version of knowledge through interpretation, organization, and cumulative development of ideas (Ackermann, 2001; Fosnot \& Perry, 1996). While both are concerned with how knowledge can be cumulatively constructed, Vygotsky emphasizes the importance of social interactions in enhancing the process of learning (Phillips, 1995). Thus, social constructivists argue that students learn best when they are able to situate their learning within a social context that enables them to internalize concepts (Cobb, 2016; Nyikos \& Hashimoto, 1997).

Design thinking is deeply rooted in the constructivist approach to learning. Design thinking consists of a set of procedures that enable the learners to embrace ambiguity (Collins, 2013; Leifer \& Steinert, 2011). In this paradigm, design thinkers are encouraged to move away from the quest for absolute answers and to engage in deductive reasoning through exploration of impartial and imperfect answers (Collins, 2013). This process enables the learners to engage in deep analysis and to internalize concepts and ideas.

Furthermore, design thinking emphasizes and builds learners' communication and collaboration skills, both of which are at the heart of constructivism. STEAM learning begins by defining a real-life problem (Boakes, 2020) and then responding to it by focusing on problemsolving skills (Herro, Quigley, Andrews, \& Delacruz, 2017) and collaborative teamwork (Jolly, 2014). Design thinking shifts the focus from individual work to team collaboration through interviewing, needs finding, data synthesizing, and prototyping. This process of engagement with peers provides opportunities for learners to listen, negotiate ideas, and construct knowledge collectively, expanding their individual zone of proximal development (Nyikos \& Hashimoto, 1997).

Design thinking has become increasingly common and relevant in educational contexts precisely because it centers around problem-solving that enhances the learner's deeper understanding of needs, challenges, and issues (Goldman \& Kabayadondo, 2016). This process provides a framework for participants to address complex, global issues by identifying diverse solutions (Noweski et al., 2012; Scheer, Noweski, \& Meinel, 2012). The skills emphasized in design thinking, such as critical thinking, creativity, competence, collaboration, and communication, are all considered essential skills in the twenty-first century (Rotherham \& Willingham, 2009; Trilling \& Fadel, 2009). The complexity of global issues demands students capable of addressing real-world problems (Brown \& Wyatt, 2010; Kelley \& Knowles, 2016). Furthermore, design thinking enables us to tackle so-called wicked problems (Rittel \& Webber, 1973) that we encounter on a day-to-day basis but that remain difficult to solve. Design thinking harnesses these skills through interactive, student-centered learning modules (Wrigley \& Straker, 2017) and enables students to become agents of change (Carroll et al., 2010). The emphasis on and value of creativity, collaboration, and innovation has spurred educators to apply design thinking in learning circles, leading to the increased use of design thinking in educational contexts over the years.

The rationale for using design thinking in education is grounded in the findings of previous studies that point to the approach's positive influence on learners. Design thinking strategies have been demonstrated to improve students' problem-solving skills, especially among lower achieving students (Chin et al., 2019). Furthermore, design thinking increases students' creativity (Gözen, 2015), as measured by the learner's creative confidence (Rauth, Köppen, Jobst, \& Meinel, 2010). In a study focusing on middle school students, Carroll (2014) documents how design thinking fosters mentorship, promotes collaboration, and inspires students to consider STEM careers. Exposure to design thinking also transforms young adolescents' perception of engineers as designers, innovators, and scientists (Goldman, Zielezinski, Vea, BachasDaunert, \& Kabayadondo, 2016). It also offers teachers new pedagogical tools (Noweski et al., 2012) to innovate on their curriculum. Furthermore, the results of this study have strong policy implications in the adoption and utilization of design thinking as a pedagogical approach to increase the number of students under-represented in STEM fields, such as girls and minority students, in learning communities around the world. The human-centered approach in design thinking (Brown, 2009; Brown \& Wyatt, 2010; Kimbell, 2011) also resonates with "A" in STEA $M$ due to the former's emphasis on empathy. This study answers the need for more research to address the potential of design thinking in promoting and accelerating STEAM learning (Li et al., 2019b).

\section{Literature review}

In this section, we conduct a critical literature review of factors associated with female youths' interest in STEM. 
Various meta-analyses have provided rich accounts and evidence of interventions that positively impact girls' interests and aspirations to pursue STEM fields (van den Hurk, Meelissen, \& van Langen, 2019; Wang \& Degol, 2013). We review three bodies of literature that directly inform the analytical framework of this study. First, we examine educational interventions that focus on utilizing existing structures, such as schools and after-school programs, to reduce the gender gap in STEM subjects. Second, we survey findings that evaluate the role of mentors in shaping female youths' perceptions and understandings of STEM pathways. Third, we draw on insights from psychological interventions that focus on improving non-cognitive factors, such as self-efficacy.

\section{Increase opportunities: in-school and out-of-school STEM programs}

One of the ways to increase girls' interest in STEM is to offer more STEM opportunities within and beyond school contexts. On average, girls pursue fewer courses in mathematics and science (Lehrer, Jacobson, Kemeny, \& Strom, 1999), which makes them less prepared to advance to higher levels of mathematics and science in post-secondary institutions (Buday, Stake, \& Peterson, 2012). Early experiences influence students' perceptions of STEM (Blickenstaff, 2005). Some proven interventions range from an online biology course (Kara \& Yeşilyurt, 2008) to a targeted STEM program for minority students (Schultz et al., 2011). Scholars advocate redesigning educational experiences to benefit girls, such as offering less biased curricular content (e.g., addressing bias in textbooks that depict more male than female figures) (Blickenstaff, 2005). Another way to address gender bias would be to offer an educational curriculum that targets girls specifically. While the effectiveness of single-gender programs is mixed (Wang \& Degol, 2013), there is some evidence to suggest that girls perform better in mathematics and science in a single-gender program (Cherney \& Campbell, 2011). For example, single-gender classrooms can increase female students' persistence in STEM and increase the likelihood that they will take additional STEM courses beyond their regular courses (Shapka \& Keating, 2003).

\section{STEM socialization: role models}

Female STEM students may experience a "chilly climate" that lacks social support for women within those fields, thus contributing to their sense of isolation and alienating others from entering STEM (Blickenstaff, 2005; Wang \& Degol, 2013). Furthermore, younger female students may be socialized to think that STEM is not right for them at a very early phase in their learning. To reverse this trend, role models can play a positive impact on female students' perceptions of STEM (Lockwood,
2006; Weber, 2011). When women are paired with mentors, who provide consultations and support, or experts of the same gender interested in STEM, they exhibit increased positive attitudes toward STEM (Blickenstaff, 2005). In a study that focused on students in postsecondary institutions, the presence of female role models increased the subjects' self-efficacy in STEM and resulted in positive perception and greater identification with STEM (Stout, Dasgupta, Hunsinger, \& McManus, 2011). The presence of female mentors also resulted in higher academic performance among younger female students in mathematics (Marx \& Roman, 2002) and science (Buday et al., 2012). Near-peer mentors (e.g., undergraduate or graduate students) can also have a positive influence on students' perceptions of STEM (Tenenbaum, Anderson, Jett, \& Yourick, 2014; van den Hurk et al., 2019). When female adolescents are surrounded by other female peers interested in STEM, they are more likely to pursue STEM (Raabe, Boda, \& Stadtfeld, 2019).

\section{Changing mindset: self-efficacy}

Researchers have focused on psychological and sociocultural factors that affect students' aptitudes and performance in the areas of science and mathematics (Eccles, 1994; Eccles, Jacobs, \& Harold, 1990). They argue that non-cognitive factors, such as self-efficacy and selfconcept (Bandura, 1986, 1989), play a significant role in their performance in STEM subjects. In STEM-related fields like engineering, female students exhibit lower levels of self-efficacy than their male counterparts (Eddy \& Brownell, 2016; Hackett \& Betz, 1981). This is especially true among the highest achievers (Halpern et al., 2007), which may be due to the fact that highperforming female students have a harder time coping with failures and setbacks because of a sudden loss of belief in their own effectiveness (Dweck, 2007a).

The literature on growth mindset provides us with a framework to understand how learners deal with failure. Growth mindset is a belief held by individuals that abilities can be developed, as opposed to the belief that abilities are fixed and that intelligence is innate (Dweck, 2007b). Children and youths who hold strong beliefs about their mindsets are influenced by their role models, such as parents and teachers (Haimovitz \& Dweck, 2016). Students with a growth mindset perform better than students with a fixed mindset in mathematics over time (Blackwell, Trzesniewski, \& Dweck, 2007). A nationally representative study of growth mindset intervention shows an overall increase in student learning outcomes among lower-achieving students as measured by their GPA, and a higher uptake of advanced mathematics courses among higher-achieving students (Yeager et al., 2019). Furthermore, motivational messages about 
the malleability of intelligence can positively impact female students' self-efficacy (Burnette, Russell, Hoyt, Orvidas, \& Widman, 2018; Degol, Wang, Zhang, \& Allerton, 2018). Female students with positive selfefficacy and a growth mindset are less affected by gender stereotypes (Good, Rattan, \& Dweck, 2012). These studies show that it is especially important for young female students to be able to counter any negative messages with messages of growth mindset as they enter the STEM pipeline. The findings from these studies have helped inform the design of this educational intervention, emphasizing concepts such as not being afraid of making mistakes through iteration and prototyping.

\section{Methods}

\section{Profile of youths}

In total, 103 youths participated in the STEAM design thinking workshop. These female youths ranged from 13 to 18 years of age (and thus in sixth to ninth grade). Approximately two-thirds of the youths attended private school, and over half of the youths had mothers working full-time. Youths participated from various prefectures including Hokkaido, Fukushima, Kanagawa, Tokyo, Chiba, Shiga, Kyoto, Osaka, Hyogo, Kumamoto, Kagoshima, and Okinawa as well as from the USA (California, New York, and New Jersey). A total of 97 youths completed the survey (Table 1).

\section{Data collection}

Data collection spanned a period of 4 years between July 2016 and June 2020. This particular design thinking and STEAM workshop was conducted five times, with each session consisting of 18-24 participants. The workshops were held in Tokyo, Japan. There are no repeat participants in the sample, and the sample consists of youths who successfully completed the workshop. ${ }^{3}$ First, youth surveys were employed to collect quantitative data. We gathered data from $97 \mathrm{fe}-$ male middle and high school youths. The participants of the workshop were given pre- and postintervention surveys. Second, a total of 19 interviews were conducted after the workshop. The interviews were structured around key analytical constructs similar to those used in the survey; however, the purpose of interviews was to obtain stories that could highlight participants' experiences and perceptions.

\section{Data analysis}

The study used the mixed-methods sequential explanatory design approach (Creswell \& Clark, 2017). In this mixed-methods approach, qualitative data are

\footnotetext{
${ }^{3}$ During the 3-year period, two students dropped out of the program, citing health reasons.
}

Table 1 Description of sample

\begin{tabular}{|c|c|}
\hline & $\%$ of Sample \\
\hline Gender, female, self-declared $(n=97)$ & 100 \\
\hline \multicolumn{2}{|l|}{ Birth Year $(n=88)$} \\
\hline 1999 & 4.5 \\
\hline 2000 & 21.6 \\
\hline 2001 & 17.0 \\
\hline 2002 & 18.2 \\
\hline 2003 & 23.9 \\
\hline 2004 & 4.5 \\
\hline 2005 & 6.8 \\
\hline 2006 & 3.4 \\
\hline \multicolumn{2}{|l|}{ Type of school $(n=92)$} \\
\hline Private & 73.9 \\
\hline Public & 17.4 \\
\hline International & 8.7 \\
\hline \multicolumn{2}{|l|}{ Grade in school $(n=90)$} \\
\hline Middle school, year 1 & 22.2 \\
\hline Middle school, year 2 & 24.4 \\
\hline Middle school, year 3 & 16.7 \\
\hline High school, year 1 & 18.9 \\
\hline High school, year 2 & 13.3 \\
\hline High school, year 3 & 4.4 \\
\hline \multicolumn{2}{|l|}{ Parents' employment status } \\
\hline \multicolumn{2}{|l|}{ Mother $(n=90)$} \\
\hline Mother does not work & 24.4 \\
\hline Mother works part-time & 20.0 \\
\hline Mother works full-time & 55.6 \\
\hline \multicolumn{2}{|l|}{ Father $(n=92)$} \\
\hline Father does not work & 2.2 \\
\hline Father works part-time & 2.2 \\
\hline Father works full-time & 95.7 \\
\hline \multicolumn{2}{|l|}{ Parent in a STEM field } \\
\hline Mother works in a STEM field $(n=93)$ & 14.0 \\
\hline Father works in a STEM field $(n=91)$ & 37.4 \\
\hline
\end{tabular}

used to complement or strengthen the key findings from quantitative analysis (Creswell \& Clark, 2017). First, we chose survey data collection in order to collect systematic responses regarding student attitudes, preferences, and beliefs from a large number of participants (Weisberg, Krosnick, \& Bowen, 1996). The youth surveys consisted of items that directly address the analytical constructs of this study: (1) interests and perceptions toward subjects: art, social science, language, mathematics, science, and engineering ${ }^{4}$; (2) 
creative confidence ${ }^{5}$; (3) career plans ${ }^{6}$; (4) growth mindset $^{7}$; (5) perceptions toward failure ${ }^{8}$; (6) aspirations for $\mathrm{STEM}^{9}$; and (7) pro-social ${ }^{10}$ constructs, in addition to background information. The questions on creative confidence are similar to those validated by Dosi, Rosati, and Vignoli (2018). ${ }^{11}$ The survey items were structured so that the responses were generated using Likert scales (scale of 1-6). The results of surveys were analyzed using a pairwise $t$ test, and Cohen's $d$ effect sizes are reported. Second, qualitative data collection using interviews were conducted after the intervention. The constructs in the interview protocol included (1) classes/academic interests ${ }^{12}$, (2) career goals ${ }^{13}$, (3) role models ${ }^{14}$, and (4) experiences in the design thinking workshop. ${ }^{15}$ The audiorecorded interviews were transcribed, and the content was analyzed. The selected excepts were minimally edited, including grammatical mistakes, to strike a balance between maintaining the authenticity of

\footnotetext{
${ }^{4}$ An example of a question related to engineering: "I like to imagine creating new products."

${ }^{5}$ Items related to creative confidence were developed by Royalty, Oishi, and Roth (2013).

${ }^{6}$ An example of a career-related question is: "I would consider a career in science."

${ }^{7}$ An example of a growth mindset-related question is: "You have a certain amount of intelligence, and you really cannot do much to change it" (Dweck, 2007b; Mangels, Butterfield, Lamb, Good, \& Dweck, 2006). In this case, respondents agreeing with this statement would count as not having a growth mindset.

${ }^{8}$ An example of a question related to failure is: "Experiencing failure limits learning and growth." (Haimovitz \& Dweck, 2016, 2017)

${ }^{9}$ An example of a question related to aspirations for STEM is: "I would consider a career in science."

${ }^{10}$ An example of a question related to a pro-social indicator is: "If you want to make the world a better place, you should pursue a career in STEM."

${ }^{11}$ Questions that measure "creative confidence" provided by Dosi et al. (2018) are (1) I think I can use my creativity to efficiently solve even complicated problems; (2) I am comfortable to think something new, different from what already exists; (3) I am sure I can deal with problems requiring creativity; and (4) I believe in my abilities to creatively solve a problem. The questions we used to measure creative confidence in our survey asked respondents to indicate (using a 6point Likert Scale) their confidence to (1) effectively work on a problem that does not have an obvious solution; (2) share your work with others before it is finished to your satisfaction; (3) try an approach to a problem or task that you know may not be the final or best solution; (4) continue to work on a problem after experiencing a significant failure; (5) help others be more creative; and (6) solve problems in ways that others would consider creative.

${ }^{12}$ An example of a question related to STEM classes: "Are you taking any classes in STEM this year?"

${ }^{13}$ An example of a question related to career goals: "Have you considered a career in STEM?"

${ }^{14}$ An example of a question related to STEM fields: "Do you have any role models in the STEM fields?"

${ }^{15}$ An example of a question related to the design thinking workshop specifically: "Has your perception and understanding of what a career in STEM would be like stay or change after participating in the workshop?"
}

participants' voices and enhancing the readers' understanding of the excerpts (Oliver, Serovich, \& Mason, 2005). Pseudonyms are used in order to protect participants' identity.

\section{The intervention}

Five phases of the STEAM design thinking process

Each STEAM design thinking workshop spanned three and a half days. Participants were introduced to design thinking as a progression of five stages of-from empathy-building to needs-finding, brainstorming, prototyping, and testing. We emphasized that design thinking is a nonlinear process (Goldschmidt \& Weil, 1998). A sixth phase, the presentation pitch, was added in order to enable the youths to hone their collaborative skills through presentation and storytelling.

\section{Phase I: empathy building}

Youths learned about the user by conducting an indepth interview. An example of a user from the 2016 workshop is a retired senior citizen in her 60s who was taking care of her ailing mother. After the interview, the youths went through an art-based portrait session in order to synthesize the findings in abstract terms. Using pastels, pencils, colored pencils, the youths developed a visual representation of the users' needs.

\section{Phase II: needs finding}

In this phase, youths analyzed the content of the interview using an empathy map and an insight identification procedure. The output of this phase is the development of a needs statement.

\section{Phase III: ideation}

Using colorful post-its, youths jotted one idea per post-it to share on the wall. Prompts were used to encourage participants to think out of the box, such as: "Your team was just given an opportunity to work with a famous pop star," or "You need to implement this idea in outer space (without gravity)." These prompts were meant to enable youths to think creatively, get out of their comfort zone, and work with imaginative ideas in order to spur creativity.

\section{Phase IV: prototyping}

Using basic prototyping materials such as recycled plastic bottles and cardboards, glue, tapes, scissors, and play dough, teams developed tangible products that could be tested. The teams tested their prototypes with the user and iterated the prototypes in subsequent steps.

\section{Phase V: presentation}

On the third day of the workshop, youths presented their work to a panel of guest commentators, consisting 
of experts such as venture capitalists, product designers, academics, and executive leaders of start-up companies. Each team delivered a 5-min pitch and answered questions from the commentators.

\section{Unique features of the program Near-peer mentors}

A near-peer mentoring system was embedded in the program given previous findings suggesting that such mentoring helps to increase STEM interest in students (Tenenbaum et al., 2014; van den Hurk et al., 2019). Each team consisted of four youths, grouped according to their age and proficiency in English (not all girls were fluent in English) and to reflect the diversity of the applicants in each session. One or two design coach(es) were assigned to each group. These design coaches were bilingual undergraduate or graduate students who could serve as mentors to youths. They guided, facilitated, and translated for the participants. They also provided strong support to the youths through words of encouragement and reminders to think out of the box and not be afraid to make mistakes.

\section{Design challenges: local solutions addressing global issues}

The design challenges given to teams varied in topic from year to year. The common thread across all years was a focus on global issues using local solutions. In year 1 , the topic was technology and senior citizens. This topic was selected in order to address the issue of population decline in Japan and explore the potential of technology to ameliorate senior citizens' overall quality of living. This challenge was also selected to foster intergenerational communication, as young people often lack opportunities to interact with senior citizens and vice versa. In year 2 , the topic focused on women engineers in Japan. To implement this program, women senior engineers and STEM managers from prominent companies were invited as users. In years 3 and 4, the design challenges were framed using the United Nation's Sustainable Development Goals, highlighting local issues with global implications, such as access to education, water, food sustainability, and environmental issues.

\section{Involvement of women STEM leaders}

Women STEM leaders were invited to the workshops. Their presence helped to "normalize and humanize" STEM fields so that the participants could better understand what it is like to become a leader in STEM fields (Roberts et al., 2018, p. 11). Women STEM leaders were invited to the program from prominent design and manufacturing companies based in Japan. The participants heard the women's life stories, their pathways to STEM fields, and the various challenges they faced in their professions.

\section{Site visit}

After the 3-day workshop, youths participated in a site visit to see women STEM leaders in action. In the past, the youths participated in a site visit to a design consultancy firm. During these visits, the participants were able to interact with STEM leaders and see firsthand how design thinking is applied in the real world. They engaged in a curated group activity to reflect on what their ideal STEM career might look like. This interactive and reflective exercise enabled youths to internalize the experiences they had in the workshop.

\section{Results}

This section reports five key findings from surveys and interviews. These findings illustrate the changes in participants' perceptions, mindsets, and interest in STEM. In addition to the primary objective of increasing youths' interest in STEM, we also observed changes in their creative confidence, empathy, and pro-social constructs (see Table 2).

\section{Finding 1: increased interest in engineering}

We observed measurable changes among youths who participated in the workshop. After the 3-day intervention, there were improvements in youths' perceptions, interest, and self-efficacy vis-à-vis engineering. This is in alignment with the focus of the workshop on engineering; the youths spent most of their time designing solutions to a given problem. There were changes in youths' perceptions toward engineering measures, as reflected in their responses (on a Likert scale of 1-strongly disagree to 6-strongly agree) to items such as "I like to imagine creating new products." The results of the paired-sample $t$ tests show that the mean differs before participating in the workshop $(M=4.50, S D=1.05)$, and after participating in the workshop $(M=4.77, S D=.86 ; t(83)=-2.58, p$ $=.012, d=.29)$. Youths also gained an understanding that engineering is a job that improves others' lives, as revealed in quotes such as: "If I learn engineering, then I can improve things that people use every day." There was a statistically significant difference in the score for this variable before the program $(M=3.88$, $S D=.96)$ and after the program $(M=4.25, S D=.86$; $t(83)=-3.93, p<.001, d=.40)$. After participating, youths were more strongly inclined to consider engineering as a way to solve world issues. This was reflected in an increased desire by youths "to design things that improve the world." Again, there was a measurable change in this variable before $(M=4.45$, $S D=.97)$ and after the program $(M=4.71, S D=.91$; $t(83)=-2.47, p=.016, d=.28)$. The following excerpt encapsulates a participant's post-workshop enthusiasm toward engineering: 
Table 2 Survey results

\begin{tabular}{|c|c|c|c|c|c|c|c|c|c|}
\hline \multirow[t]{2}{*}{ Variable } & \multicolumn{2}{|c|}{$\begin{array}{l}\text { Baseline } \\
\text { Survey }\end{array}$} & \multicolumn{3}{|c|}{$\begin{array}{l}\text { Post- } \\
\text { intervention } \\
\text { survey }\end{array}$} & \multicolumn{3}{|c|}{ Paired $t$ tests } & \multirow{2}{*}{$\begin{array}{l}\text { Effect size } \\
\text { Cohen's } d\end{array}$} \\
\hline & $M$ & $S D$ & $\bar{M}$ & $S D$ & $N$ & $t$ & $p$ & $d f$ & \\
\hline \multicolumn{10}{|l|}{ Engineering and design } \\
\hline I like to imagine creating new products & 4.50 & 1.05 & 4.77 & .86 & 84 & -2.58 & .012 & 83 & 0.29 \\
\hline If I learn engineering, then I can improve things that people use every day & 3.88 & .96 & 4.25 & .86 & 84 & -3.93 & $<.001$ & 83 & 0.40 \\
\hline I am interested in what makes machines work & 3.89 & 1.13 & 4.12 & 1.04 & 83 & -2.13 & .036 & 82 & 0.21 \\
\hline I want to design things that improve the world & 4.45 & .97 & 4.71 & .91 & 84 & -2.47 & .016 & 83 & 0.28 \\
\hline \multicolumn{10}{|l|}{ Creative confidence } \\
\hline I can effectively work on a problem that does not have an obvious solution & 3.81 & 1.10 & 4.10 & .87 & 81 & -2.46 & .016 & 80 & 0.29 \\
\hline I am able to share my work with others before it is finished to my satisfaction & 3.84 & 1.12 & 4.10 & 1.09 & 81 & -2.37 & .020 & 80 & 0.23 \\
\hline The effects of failure are negative and should be avoided & 2.51 & 1.14 & 2.16 & 1.11 & 76 & 2.61 & .011 & 75 & -0.32 \\
\hline I believe I can be successful & 3.23 & .99 & 3.48 & 1.03 & 82 & -2.15 & .034 & 81 & 0.24 \\
\hline \multicolumn{10}{|l|}{ STEM } \\
\hline People who study STEM tend to work alone in labs & 3.44 & .93 & 2.96 & .98 & 27 & 2.80 & .010 & 26 & -0.50 \\
\hline STEM is mostly about technical knowledge & 3.96 & .85 & 3.59 & .80 & 27 & 2.08 & .048 & 26 & -0.45 \\
\hline \multicolumn{10}{|l|}{ Pro-social } \\
\hline People who study STEM tend to care about other people & 4.03 & .99 & 4.45 & .94 & 64 & -3.12 & .003 & 63 & 0.44 \\
\hline If you want to make the world a better place, you should pursue a career in STEM & 3.74 & .97 & 4.15 & 1.04 & 81 & -3.68 & $<.001$ & 80 & 0.41 \\
\hline \multicolumn{10}{|l|}{ Career/Future Aspirations } \\
\hline I would consider a career in science & 3.17 & 1.50 & 3.54 & 1.42 & 76 & -3.29 & .002 & 75 & 0.25 \\
\hline I can see myself starting my own company/business & 3.43 & 1.14 & 3.63 & 1.10 & 80 & -2.11 & .038 & 79 & 0.18 \\
\hline If I have children, I see myself staying in the workforce & 4.65 & 1.18 & 4.86 & .99 & 83 & -2.06 & .043 & 82 & 0.19 \\
\hline
\end{tabular}

It [my goal] has changed slightly, particularly because of the influence of participating [in the workshop], and after participating I decided that I want to become an engineer. I love science as well, so I am thinking of [becoming] something like an engineer scientist, combining science and engineering... I cannot be $100 \%$ sure that I will be successful, and I do worry, but nothing starts without taking [on] challenges, so you cannot [just] think about risks and not move forward. So even though I'm not $100 \%$ confident, I do have a strong feeling that I will do it anyways. (Kae)

Findings show that the participants' perceptions toward engineering shifted; they now view engineers as people who exhibit various traits, such as creativity, technical knowledge, and problem-solving skills, and they were able to imagine themselves as engineers. In the next section, we discuss the changes in participants' creative confidence.

\section{Finding 2: changes in creative confidence}

The second key finding from the STEAM design thinking workshop was an increase in participants' creative confidence. In this study, creative confidence is a measurement of individuals' ability to work under conditions of uncertainty, as well as their openness to feedback and critiques of ideas still in progress (Kelley \& Kelley, 2013). It is also related to their willingness to persist, demonstrating grit, after experiencing a moment of failure, or coming up with ways to address issues when setbacks arise (Duckworth, 2016). The surveys showed that participating in the workshop made youths more confident to work under difficult conditions and to obtain feedback and critiques, even when their ideas were not fully developed. There was significant change in their attitude toward working on open-ended questions before the intervention $(M=$ $3.81, S D=1.10)$ and after the intervention $(M=$ 4.10, $S D=.87 ; t(80)=-2.46, p=.016, d=.29)$. Some examples of the participants' insights, as revealed in interviews, included:

I found it unexpectedly easy to create something new. I found that we can actually come up with and create something by exchanging ideas over just three days, rather than thinking about it for years. (Kaori) 
[At this workshop], they don't care about the quality at all. I really liked it when they said, 'Come up with any ideas you have in mind without worrying about getting judged asking questions or suggestions.' (Manami)

The participants were encouraged to go through a rapid trial-and-error process. This bias toward action (Kelley \& Kelley, 2013; Schweitzer, Groeger, \& Sobel, 2016) to test early-phase prototypes for further iteration and development is at the core of entrepreneurship (Ries, 2011). The participants were asked how they would respond if asked to share their work with others before finishing that work to their own satisfaction. Before the workshop, the participants were hesitant to share $(M=3.84, S D=1.12)$, but the results of the postintervention survey suggest that they became more confident to share ideas that are still in progress with others $(M=4.10, S D=1.09$; $t(80)=-2.37, p=.02, d=$ .23). This entrepreneurial spirit was elevated during the workshop, enhancing the sense of creative confidence among the participants.

We also observed that girls who participated in the workshop felt self-conscious at first about voicing their opinions and sharing them with a large number of people, including their male cohorts. The results of the survey show that the participants' sense of creative confidence increased over the course of the program. Prior to the workshop, the participants expressed a lower confidence that they could be successful $(M=3.23, S D=$ .99) than they did after the intervention $(M=3.48, S D=$ 1.03; $t(81)=-2.15, p=.034, d=.24)$. Participating in the workshop broke barriers for these girls and empowered them to feel more comfortable voicing their thoughts.

[I learned that] It is important to speak your thoughts, and that I unintentionally restricted myself from doing so in certain occasions around boys and in a larger number of people. (Hitomi)

I think it was very good to have an atmosphere where people could express their opinions without denying the opinions of others. In Japanese classrooms, people tend to worry about whether they have the right answer or not, or what the people might think of them, so few people speak up. In this workshop, all the groups were speaking up, and even I, who usually can't speak up, was able to say what I thought without hesitation. I thought it would be great if my class could be more active like this. (Suzuka)
These excerpts help us to understand that participating in the workshop encouraged the participants to share their voice and feel a greater sense of agency. In this process, the youths felt that their voice was valued and their ideas could lead to innovations.

Furthermore, findings show that female youths' attitudes toward failure, a measurement of creative confidence, also shifted. After participating in the workshop, more girls disagreed that the effects of failure were negative and should be avoided, with the mean score decreasing from pre-workshop $(M=2.51, S D=1.14)$ to post-workshop $(M=2.16, \mathrm{SD}=1.11 ; t(75)=2.61, p=$ $.011, d=-.32$ ). The following excerpt shows how the workshop changed one participant's attitude toward failure:

I'm not great at creating something from scratch, but I realized that there's a role I can play in that. Prior to this experience, if I didn't like something, I would do my best to avoid it. Through this experience, though, I felt like there was something even I can do. Perhaps others are better at creating something from scratch, but when it comes to developing it or making it into something bigger, I think there's something that I can contribute. (Akemi)

The rise in the participants' creative confidence was one of the most revealing findings in our study. Japanese students are used to learning in schools that emphasize strong notions of what is correct and incorrect. The Japanese college entrance examination system trains students to master test-taking skills, while focusing little attention on critical thinking skills (Yamamura, 1989). Participation in the design thinking and STEAM workshop increased the participants' creative confidence. This frame of mind, which strengthens youths' confidence to tackle difficult, complex, and global issues, was one of the key changes we observed among youths who participated in the program.

Before participating in this workshop um I was, I thought I was [a] very close-minded person and um wasn't good communicator, but um as I participate in the workshop, I was the oldest one in my group and then I sort of led them to speak up and then like express their opinion so I guess I wasn't [a] very close-minded person. (Lisa)

Hmm, about myself...well, when I made the prototype, I have a rather cautious personality, but to put together and shaping your thinking into a concrete form, you kind of have to keep going with a rough idea in mind without caring too much about it 
being messed up. I also never had the experience to just keep doing things as ideas come, or speak up for myself, so that kind of thinking. It was refreshing having to behave like that, and I think I was made aware of my ability to act like I had never had before. (Yui)

The findings from this study provide evidence that the participants experienced changes in their mindset, which is related to improvements in their creative confidence, such as bias toward action, and the importance of voicing their thoughts. In the next section, we discuss the changes in participants' perception of STEM.

\section{Finding 3: perceptions of STEM}

Female youths' perceptions of STEM changed and broadened after participating in the workshop. The survey asked respondents to agree or disagree with this statement: "People who study STEM tend to work alone in labs." Before the workshop, on average, the respondents fell in the "middle," neither particularly agreeing nor disagreeing with this statement $(M=3.44, S D=$ .93), but after the workshop, their perceptions of STEM specialists had changed, with an observable decline in their level of agreement $(M=2.96, S D=.98 ; t(26)=$ $2.80, p=.01, d=-.50$ ) with the above statement. This is a significant shift in the youths' perceptions of STEM toward understanding that STEM can actually lead to a variety of professions. Furthermore, prior to participating in the workshop, many youths expressed the belief that STEM fields consist of mostly technical knowledge $(M=3.96, S D=.85)$. After the workshop, there was a decline in their responses to this construct, suggesting an expanded understanding of STEM that includes and values non-technical knowledge, such as the abilities to communicate, collaborate, and be creative $(M=3.59$; $S D$ $=.80 ; t(26)=2.08, p=.048, d=-0.45)$. The following excerpt concurs with the survey findings:

Before attending [the workshop], when I thought about the people in the sciences, I would think of someone in the sciences who would always be looking at numbers and be able to solve problems instantly. I realized that they weren't just about numbers, but more about thinking outside the box, and bringing different things together. So even though I'm not great with numbers, I felt like it's something even I can do. (Kaori)

I think STEM is so important for our world. I think it encourages people to use the world around us and use it creatively to fix problems. I think that's by [participating in the workshop, it] gave me the opportunity to think about that in a bigger, real world sense. That definitely changed how important STEM is [to me]. (Rina)

These findings show that participation in the workshop enabled youths to see the work of STEM professionals as much more fluid and less technical than they might have previously imagined. This is significant as encouraging female youths to pursue STEM requires changing their understanding not only of their own facility for STEM but also of STEM fields themselves. We need, in short, a concerted effort to demystify STEM professions.

\section{Finding 4: empathy and pro-social indicators}

The fourth measurable change among youths who participated in the workshop concerned the component of empathy in STEM learning and pro-social perceptions. Studies have shown that under-represented students, such as first-generation, minority, and female students, show greater motivation to pursue STEM topics if they believe that science advances pro-social goals, such as improving the lives of others and serving their communities (Allen, Muragishi, Smith, Thoman, \& Brown, 2015; Estrada et al., 2016). We observed some meaningful shifts in the youths' pro-social attitudes. In response to the following statement: "People who study STEM tend to care about other people," there was an increase in the mean response from pre-workshop $(M=4.03, S D=.99)$ to post-workshop $(M$ $=4.45 S D=.94 ; t(63)=-3.12, p=.003, d=.44)$. This indicated an increased understanding among youths that the field of STEM is grounded in empathy. Another prosocial indicator worth highlighting is the youths' perceptions that a career in STEM is ideal for those who want to make the world a better place. Their perception changed from before the workshop $(M=3.74, S D=.97)$ to after the workshop $(M=4.15, S D=1.04 ; t(80)=-3.68, p<$ $.001, d=.41)$. The following stories also highlight how participants linked STEM with pro-social attitudes:

When we conducted an interview for a customer [user] [at the workshop], it was exciting to create a product, which satisfied the customer's [user's] needs. I realized how fun it is to help someone, and thought that I want to have a job like this, and so I want to become an engineer. (Kae)

I think with the development of science and technology, life becomes more convenient, and I think there is a possibility that we can solve various environmental problems with the development of technology. So, I imagine that this profession is something that supports that sort of development by doing research to create a brighter future for Earth. I am not saying that everything science and 
technology is good, but I have the image that they are here to improve things. (Yui)

These excerpts provide insight into how the participants grasped the concept of empathy and its relevance in creating meaningful solutions. Furthermore, the youths attributed the solution of global problems to the process of design in engineering and technology.

\section{Finding 5: career aspirations}

Youths described their increased interest in STEM fields after attending the workshop. More specifically, their desire to pursue options related to STEM was heightened. In response to the statement, "I would consider a career in science," the average before the workshop was $(M=3.17, S D=$ $1.50)$ and then increased after the workshop $(M=3.54, S D$ $=1.42 ; t(75)=-3.29, p=.002, d=.25)$. The following excerpts reflect the respondents' aspirations for STEM:

Yeah, I think it was really important to do the workshop before my senior year, especially because I'd be applying to colleges. I think it was a good confirmation that I definitely want to do work... something in STEM, but, also, try to learn, maybe, some art and tech, and try to broaden my perspective and learn more things.... Since I also like Math and Science, being able to do that., but also knowing that you're helping people, and it creates real solutions in the world, is really important, and I want to do that. (Miku).

..It [the workshop] made me look at all the different workshop[s] that was um focusing...that focused on design thinking or even STEM field, STEM fields to... girls...and then...um I-I began participating um in um IT camp that was organized by [a] Japanese company... so that was, that was very similar to what I did in design thinking but it also helped me add on to my art and science skills and so I realized... and it made me realize that I really do enjoy those two fields and then I...yeah...that brought my focus to STEAM field more. (Lisa)

The participants engaged with women STEM leaders from various industries. Several female engineers, designers, and scientists were invited to interact with participants in each session. ${ }^{16}$ The women STEM leaders

\footnotetext{
${ }^{16}$ 2016: NASA engineer and a physician; 2017: four engineers from prominent international manufacturing companies, and one senior designer; 2018: one diversity and inclusion officer from a prominent consultancy company, three engineers from international manufacturing companies; 2019: three engineers from international manufacturing companies, and one senior designer. Special guests included university professors and a former deputy director of science in the US administration.
}

talked about their decisions to pursue a career in STEM, described impactful projects they had worked on, and discussed the challenges of work-life balance. We also measured change in participants' perceptions of women's role in society. There were more participants post-workshop agreeing with the statement: "If I have children, I see myself staying in the workforce." There was a significant change pre-workshop $(M=4.65, S D=$ $1.18)$ and post-workshop $(M=4.86, S D=.99)$, suggesting that the presence of women STEAM leaders had an influence on female youths $(t(82)=-2.06, p=.043, d=$ .19). Furthermore, female youths who participated in the program also responded more positively to: "I can see myself starting my own company/business," indicating their entrepreneurial spirit. The results of the preintervention $(M=3.43, S D=1.14)$ and post-intervention $(M=3.63, S D=1.10)$ show that participation in this workshop enabled the female youths to feel that one day they could, both, have a family and become entrepreneurs, just like the STEAM women they interacted with during the workshop $(t(79)=-2.11, p=.038, d=.18)$.

\section{Discussion}

This study shows that a short, 3-day intervention can make a positive impact on young female youths' perceptions of STEM, pro-social attitudes, creative confidence, and career pathways. It does this by creating a "hook" or stimulating interest among youths to have a more favorable opinion about working in STEM.

At the same time, the study's second finding is that persistent gender norms are hard to overturn and require additional interventions. Gender norms around STEM topics are deeply embedded in sociocultural roots and pre-conceived notions of gender and thus difficult to reverse. This is evident in the analysis. We asked youths a series of questions regarding gender in STEM fields, using statements such as, "Women should pursue STEM fields in the future." We also asked the participants about their perceptions regarding women in leadership positions, using statements such as, "Girls can have greater, more positive impact on society," and "I want to inspire other girls by becoming a leader in my field." We were unable to observe meaningful changes in the responses to these questions. In their daily lives outside of such interventions, female youths experience persistent norms and social forces that still reduce their ability to imagine themselves in STEM fields or to believe that they too could become leaders and inspire other girls to follow suit.

If our collective goal is to inspire more young female youths to pursue STEM subjects, then we need to create more awareness of what STEM entails and enables, provide more opportunities and pathways into the fields, and offer extensive support for female youths to 
experiment with various branches of STEM. In Japan, there is a lack of clear consensus and provision of STEM education at the national scale (Yata, Ohtani, \& Isobe, 2020). We advocate for a systematic change that would impact the education system at large. The Ministry of Economic and Trade and Industry has recently begun an initiative to promote STEAM learning (METI, 2019); however, systematic, inter-departmental efforts will be necessary to nudge more female youths to pursue STEM. This could be done through a combination of interventions that include policies to promote more female participation in STEM programs, campaigns to increase parents' and educators' awareness of STEM, and the provision of discretionary funding for teachers to implement STEM curriculum in the classrooms. Hands-on engineering projects and supplementary courses such as virtual STEM programs could also help increase opportunities for female youths to consider STEM.

Third, this study offers strong evidence of the positive impact of a design thinking curriculum on female youths' interest in STEM. The findings suggest that girls not only changed their perception of STEM subjects but also exhibited greater empathy and felt an increased sense of belonging in STEM as a result of participating in the workshop.

The main limitation of this study is its focus on a brief educational intervention with a relatively small number of enrolled youths. Given that it was not a randomly selected group of youths, there is no comparison group and the study is prone to selection bias. Also, we encountered some difficulties in the data collection, which limited the scope of the qualitative analysis for this study. Participants were extremely hard to track after the program was over, and the double consent process (parents and minors) prohibited us from securing a large pool of respondents for the interviews. Obtaining indepth responses from young respondents also made the data collection more challenging. In the next phase of data collection, we will consider having a focus group to solicit in-depth responses. When interviewees share similar backgrounds and experiences, focus groups are likely to create interactions among the respondents and yield a desirable outcome (Creswell \& Poth, 2017).

\section{Conclusion}

Countries around the world are implementing novel ways to encourage more female youths to consider STEM careers (van den Hurk et al., 2019). We explore the influences of a short, 3-day design thinking workshop on young adolescent girls living in Japan. The study provides empirical support that such a workshop can have a positive impact on the participants, boosting their interest in STEM. In addition, the design thinking approach increased the participants' creative confidence, their empathy, and their pro-social tendencies. By providing exposure to women STEAM experts, the workshop also changed female participants' outlook on worklife balance as well. To conclude, the promise of design thinking extends far beyond the benefits of innovation and creativity; it is a viable pedagogical approach that can be used to cultivate the next generation of female STEAM thinkers.

\section{Abbreviations}

OECD: Organisation for Economic Co-operation and Development; METI: Ministry of Economics, Trade, and Industry; STEAM: Science, Technology, Engineering, Arts, and Mathematics; STEM: Science, Technology, Engineering, and Mathematics

\section{Acknowledgements}

This study received valuable support from Shelley Goldman, Tanner Vea, Keiko Okawa, Masa Inakage, Kathy Liu Sun, and Daisuke Kan. We thank Audra Wingard, Miwa Okajima, and Kenshiro Hama for their excellent research assistance. We also thank Mika Isayama, Risako Yang, Mei Maruo, and Elisa Baba for their valuable help running the workshop and collecting data. We are indebted to all the women STEM leaders and users who volunteered their time to mentor youths. Naomi Kurisu and Risako Ninomiya helped implement the workshops. We are grateful to Tom Kelley and IDEO for their support of this initiative. The research protocol was approved by the Institutional Review Board at Stanford University (\#37986 \& \#56468) and the Human Ethics Committee at the University of Toronto (\#39319).

\section{Authors' contributions}

RK conceived, designed, analyzed, and took the lead in writing the manuscript. MYY was involved in all phases of the study. She co-organized and facilitated the workshops and contributed to the development of the surveys and the interview protocol. MSM co-organized the workshops and recruited design coaches and users. All authors read and approved the final manuscript.

\section{Funding}

The manuscript was prepared and developed using grants from the Freeman Spogli Institute for International Studies at Stanford University and the Institute for Gender and the Economy at the Rotman School of Management, University of Toronto. In-kind support was provided by the Stanford Graduate School of Education and Keio University Graduate School of Media Design.

\section{Availability of data and materials}

The datasets used and analyzed during this research project are not publicly available since data were collected from minors who were under the age of 18 at the time of data collection.

\section{Competing interests}

The authors declare no competing interests for this study. RK and MYY have disseminated the research results to academic audiences, government officers, foundations, and media outlets. RK and MSM have complied with the conflict of interest disclosure requirements at their respective academic institutions. RK and MYY are co-founders of SKY Labo, a non-profit organization based in Tokyo, Japan. Currently, no financial conflict of interest has been identified since the authors do not earn any income from this organization.

\section{Author details}

${ }^{1}$ Munk School of Global Affairs and Public Policy, University of Toronto, 1 Devonshire Place, Toronto, ON M5S 3K7, Canada. ${ }^{2}$ Stanford Program on International and Cross-Cultural Education, Freeman Spogli Institute of International Studies at Stanford University, Encina Hall, 616 Jane Stanford Way, Stanford, CA 94305-6055, USA. ${ }^{3}$ Keio University Graduate School of Media Design, 4-1-1 Hiyoshi Kohoku-ku, Yokohama, Kanagawa 223-8526, Japan. 
Received: 21 April 2020 Accepted: 18 January 2021

Published online: 22 March 2021

\section{References}

Ackermann, E. (2001). Piaget's constructivism, Papert's constructionism: What's the difference? Future of Learning Group Publication, 5(3), 438 http://learning media.mit.edu/content/publications/EA.Piaget_Papert.pdf.

Allen, J. M., Muragishi, G. A., Smith, J. L., Thoman, D. B., \& Brown, E. R. (2015). To grab and to hold: Cultivating communal goals to overcome cultural and structural barriers in first-generation college students' science interest. Translational Issues in Psychological Science, 1(4), 331.

Bandura, A. (1986). The explanatory and predictive scope of self-efficacy theory. Journal of Social and Clinical Psychology, 4(3), 359-373.

Bandura, A. (1989). Human agency in social cognitive theory. American Psychologist, 44(9), 1175

Beede, D., Julian, T., Langdon, D., McKittrick, G., Khan, B., \& Doms, M. (2011). Women in STEM: A gender gap to i nnovation. ESA Issue Brief\# 04-11. In US Department of Commerce https://files.eric.ed.gov/fulltext/ED523766.pdf.

Blackwell, L. S., Trzesniewski, K. H., \& Dweck, C. S. (2007). Implicit theories of intelligence predict achievement across an adolescent transition: A longitudinal study and an intervention. Child Development, 78(1), 246-263.

Blau, F. D., \& Kahn, L. M. (2017). The gender wage gap: extent, trends, and explanations. Journal of Economic Literature, 55(3), 789-865. https://doi.org/ 10.1257/jel.20160995.

Blickenstaff, J. (2005). Women and science careers: leaky pipeline or gender filter? Gender and Education, 17(4), 369-386. https://doi.org/10.1080/ 09540250500145072

Boakes, N. J. (2020). Cultivating design thinking of middle school girls through an origami STEAM project. Journal for STEM Education Research, 3, 259-278. https://doi.org/10.1007/s41979-019-00025-8.

Borko, H. (2016). Response 1: Model-based reasoning in professional development. In R. A. Duschl, \& A. S. Bismack (Eds.), Reconceptualizing STEM Education: The Central Role of Practices, (pp. 139-144). New York: Routledge.

Brown, T. (2009). Change by design: How design thinking transforms organizations and inspires innovation. New York: Harper Business.

Brown, T., \& Wyatt, J. (2010). Design thinking for social innovation. Development Outreach, 12(1), 29-43.

Buday, S. K., Stake, J. E., \& Peterson, Z. D. (2012). Gender and the choice of a science career: The impact of social support and possible selves. Sex Roles, 66(3-4), 197-209

Burnette, J. L., Russell, M. V., Hoyt, C. L., Orvidas, K., \& Widman, L. (2018). An online growth mindset intervention in a sample of rural adolescent girls. British Journal of Educational Psychology, 88(3), 428-445.

Carroll, M., Goldman, S., Britos, L., Koh, J., Royalty, A., \& Hornstein, M. (2010). Destination, imagination and the fires within: Design thinking in a middle school classroom. International Journal of Art \& Design Education, 29(1), 3753.

Carroll, M. P. (2014). Shoot for the moon! The mentors and the middle schoolers explore the intersection of design thinking and STEM. Journal of Pre-College Engineering Education Research, 4(1), 3.

Ceci, S. J., Williams, W. M., \& Barnett, S. M. (2009). Women's underrepresentation in science: sociocultural and biological considerations. Psychological Bulletin 135(2), 218

Chen, C. W. J., \& Lo, K. M. J. (2019). From teacher-designer to student-researcher A study of attitude change regarding creativity in STEAM education by using Makey Makey as a platform for human-centred design instrument. Journal for STEM Education Research, 2(1), 75-91.

Cherney, I. D., \& Campbell, K. L. (2011). A league of their own: Do single-sex schools increase girls' participation in the physical sciences? Sex Roles, 65(910), 712-724

Chin, D. B., Blair, K. P., Wolf, R. C., Conlin, L. D., Cutumisu, M., Pfaffman, J., \& Schwartz, D. L. (2019). Educating and measuring choice: a test of the transfer of design thinking in problem solving and learning. Journal of the Learning Sciences, 28(3), 337-380.

Cobb, P. (2016). Where is the mind? A coordination of sociocultural and cognitive constructivist perspectives. In C. T. Fosnot (Ed.), Constructivism: Theory, perspectives, and practice, (pp. 34-52). Teachers College Press.

Collins, H. (2013). Can design thinking still add value? Design Management Review, $24(2), 35-39$

Creswell, J. W., \& Clark, V. L. P. (2017). Designing and conducting mixed methods research. Thousand Oaks: Sage Publications.
Creswell, J. W., \& Poth, C. N. (2017). Qualitative inquiry and research design: Choosing among five approaches, (4th ed., ). Thousand Oaks: Sage Publications, Inc

Daugherty, M. K. (2013). The Prospect of an "A" in STEM Education. Journal of STEM Education: Innovations and Research, 14(2), 10-15.

Degol, J. L., Wang, M.-T., Zhang, Y., \& Allerton, J. (2018). Do growth mindsets in math benefit females? Identifying pathways between gender, mindset, and motivation. Journal of Youth and Adolescence, 47(5), 976-990. https://doi.org/ 10.1007/s10964-017-0739-8.

Dickerson, A., McIntosh, S., \& Valente, C. (2015). Do the maths: An analysis of the gender gap in mathematics in Africa. Economics of Education Review, 46, 122.

Dosi, C., Rosati, F., \& Vignoli, M. (2018). Measuring design thinking mindset. DS 92 Proceedings of the DESIGN 2018 15th International Design Conference, 19912002. https://doi.org/10.21278/idc.2018.0493.

Duckworth, A. (2016). Grit: The power of passion and perseverance. New York: Scribner

Duschl, R. A., \& Bismack, A. S. (2016). Reconceptualizing STEM education: The central role of practices. New York: Routledge.

Dweck, C. (2007a). Is math a gift? Beliefs that put females at risk. In Why aren't more women in science?: Top researchers debate the evidence. Washington DC. C.: American Psychological Association https://psycnet.apa.org/record/2 006-22337-004

Dweck, C. (2007b). Mindset: The new psychology of success. New York: Ballantine Books.

Eccles, J. S. (1994). Understanding women's educational and occupational choices: Applying the Eccles et al. model of achievement-related choices. Psychology of Women Quarterly, 18(4), 585-609. https://doi.org/10.1111/j.14716402.1994.tb01049.x.

Eccles, J. S., Jacobs, J. E., \& Harold, R. D. (1990). Gender role stereotypes, expectancy effects, and parents' socialization of gender differences. Journal of Social Issues, 46(2), 183-201.

Eddy, S. L., \& Brownell, S. E. (2016). Beneath the numbers: A review of gender disparities in undergraduate education across science, technology, engineering, and math disciplines. Physical Review Physics Education Research, 12(2). https://doi.org/10.1103/PhysRevPhysEducRes.12.020106.

English, L. D., \& King, D. T. (2015). STEM learning through engineering design: Fourth-grade students' investigations in aerospace. International Journal of STEM Education, 2(1), 14.

Estapa, A. T., \& Tank, K. M. (2017). Supporting integrated STEM in the elementary classroom: A professional development approach centered on an engineering design challenge. International Journal of STEM Education, 4(1), 6.

Estrada, M., Burnett, M., Campbell, A. G., Campbell, P. B., Denetclaw, W. F. Gutiérrez, C. G., ... Zavala, M. (2016). Improving underrepresented minority student persistence in STEM. CBE-Life Sciences Education, 15(3), es5. https:// doi.org/10.1187/cbe.16-01-0038.

Fosnot, C. T., \& Perry, R. S. (1996). Constructivism: A psychological theory of learning. In C. T. Fosnot (Ed.), Constructivism: Theory, Perspectives, and Practice, (2nd ed., pp. 8-33). New York: Teachers College, Columbia University.

Fryer Jr., R. G., \& Levitt, S. D. (2010). An empirical analysis of the gender gap in mathematics. American Economic Journal: Applied Economics, 2(2), 210-240.

Goldman, S., \& Kabayadondo, Z. (2016). Taking design thinking to school: How the technology of design can transform teachers, learners, and classrooms. New York: Routledge.

Goldman, S., Zielezinski, M. B., Vea, T., Bachas-Daunert, S., \& Kabayadondo, Z. (2016). Taking design thinking to school: How the technology of design can transform teachers, Learners, and Classroomse. In S. Goldman, \& Z. Kabayadondo (Eds.), Taking design thinking to school: How the technology of design can transform teachers, learners, and classrooms, (pp. 90-118). New York: Routledge.

Goldschmidt, G., \& Weil, M. (1998). Contents and structure in design reasoning. Design Issues, 14(3), 85-100

Good, C., Rattan, A., \& Dweck, C. S. (2012). Why do women opt out? Sense of belonging and women's representation in mathematics. Journal of Personality and Social Psychology, 102(4), 700-717. https://doi.org/10.1037/a0026659.

Gözen, G. (2015). Influence of design thinking performance on children's creative problem-solving skills: An estimation through regression analysis. Journal of Education, Society and Behavioural Science, 12(4), 1-13.

Guiso, L., Monte, F., Sapienza, P., \& Zingales, L. (2008). Culture, gender, and math. Science, 320(5880), 1164-1165. 
Hackett, G., \& Betz, N. E. (1981). A self-efficacy approach to the career development of women. Journal of Vocational Behavior, 18(3), 326-339. https://doi.org/10.1016/0001-8791(81)90019-1.

Haimovitz, K., \& Dweck, C. (2016). Parents' views of failure predict children's fixed and growth intelligence mind-sets. Psychological Science, 27(6), 859-869.

Haimovitz, K., \& Dweck, C. S. (2017). The origins of children's growth and fixed mindsets: New research and a new proposal. Child Development, 88(6), 18491859.

Halpern, D. F., Benbow, C. P., Geary, D. C., Gur, R. C., Hyde, J. S., \& Gernsbacher, M. A. (2007). The science of sex differences in science and mathematics. Psychological Science in the Public Interest, 8(1), 1-51. https://doi.org/10.1111/j. 1529-1006.2007.00032.x.

Herro, D., Quigley, C., Andrews, J., \& Delacruz, G. (2017). Co-measure: developing an assessment for student collaboration in STEAM activities. International Journal of STEM Education, 4(1), 26.

Jolly, A. (2014). STEM vs. STEAM: Do the arts belong. Education Week. https:// www.edweek.org/teaching-learning/opinion-stem-vs-steam-do-the-artsbelong/2014/11

Kara, Y., \& Yeşilyurt, S. (2008). Comparing the impacts of tutorial and edutainment software programs on students' achievements, misconceptions, and attitudes towards biology. Journal of Science Education and Technology, 17(1), 32-41.

Kato, M., \& Chayama, H. (2012). Nihon no daigaku kyouin no jyosei hiritsu ni kansuru bunseki [Analysis of the ratio of women in science in Japan]. https:// www.nistep.go.jp/wp/wp-content/uploads/mat209j.pdf

Kelley, D., \& Kelley, T. (2013). Creative confidence: Unleashing the creative potential within us all. New York: Crown Publishing Group.

Kelley, T., \& Knowles, J. G. (2016). A conceptual framework for integrated STEM education. International Journal of STEM Education, 3(1), 11.

Kerr, B., \& Kurpius, S. E. (2004). Encouraging talented girls in math and science: Effects of a guidance intervention. High Ability Studies, 15(1), 85-102. https:// doi.org/10.1080/1359813042000225357.

Kimbell, L. (2011). Rethinking design thinking: Part I. Design and Culture, 3(3), 285306.

Lehrer, R., Jacobson, C., Kemeny, V., \& Strom, D. (1999). Building on children's intuitions to develop mathematical understanding of space. In E. Fennema, \& T. A. Romberg (Eds.), Mathematics classrooms that promote understanding, (pp. 57-77). New York: Routledge.

Leifer, L., \& Steinert, M. (2011). Dancing with ambiguity: Causality behavior, design thinking, and triple-Loop Learning. Information Knowledge Systems Management, 10, 151-173.

Li, Y., Schoenfeld, A. H., DiSessa, A. A., Graesser, A., Benson, L., English, L. D., \& Duschl, R. A. (2019b). On thinking and STEM education. Journal for STEM Education Research, 2, 1-13.

Li, Y., Schoenfeld, A. H., DiSessa, A. A., Graesser, A., Benson, L. C., English, L. D., \& Duschl, R. A. (2019a). Design and design thinking in STEM education. Journal for STEM Education Research, 2, 93-104.

Lockwood, P. (2006). "Someone like me can be successful": Do college students need same-gender role models? Psychology of Women Quarterly, 30(1), 36-46.

Madden, M. E., Baxter, M., Beauchamp, H., Bouchard, K., Habermas, D., Huff, M., ... Plague, G. (2013). Rethinking STEM education: An interdisciplinary STEAM curriculum. Procedia Computer Science, 20, 541-546.

Mangels, J., Butterfield, B., Lamb, J., Good, C., \& Dweck, C. (2006). Why do beliefs about intelligence influence learning success? A social cognitive neuroscience model. Social Cognitive and Affective Neuroscience, 1(2), 75-86.

Marx, D. M., \& Roman, J. S. (2002). Female role models: Protecting women's math test performance. Personality and Social Psychology Bulletin, 28(9), 1183-1193.

Mcllwee, J. S., \& Robinson, J. G. (1992). Women in engineering: Gender, power, and workplace culture. New York: SUNY Press.

Meinck, S., \& Brese, F. (2019). Trends in gender gaps: using 20 years of evidence from TIMSS. Large-Scale Assessments in Education, 7(1), 1-23.

METI. (2019). Visions of the "Future Classroom" Program Compiled as Effort towards Educational Reform in the Reiwa Era. https://www.meti.go.jp/ english/press/2019/0625_002.html

Noweski, C., Scheer, A., Büttner, N., von Thienen, J., Erdmann, J., \& Meinel, C. (2012). Towards a paradigm shift in education practice: Developing twentyfirst century skills with design thinking. In Design thinking research, (pp. $71-$ 94). Cham: Springer International Publishing.

Nyikos, M., \& Hashimoto, R. (1997). Constructivist theory applied to collaborative learning in teacher education: In search of ZPD. The Modern Language Journal, 81(4), 506-517.
OECD. (2020). Gender Wage Gap. OECD Data. https://data.oecd.org/earnwage/ gender-wage-gap.htm

Oh, S. S., \& Lewis, G. B. (2011). Stemming inequality? Employment and pay of female and minority scientists and engineers. The Social Science Journal, 48(2), 397-403

Oliver, D. G., Serovich, J. M., \& Mason, T. L. (2005). Constraints and opportunities with interview transcription: Towards reflection in qualitative research. Social Forces, 84(2), 1273-1289.

Phillips, D. C. (1995). The good, the bad, and the ugly: The many faces of constructivism. Educational Researcher, 24(7), 5-12.

Raabe, I. J., Boda, Z., \& Stadtfeld, C. (2019). The social pipeline: how friend influence and peer exposure widen the stem gender gap. Sociology of Education, 92(2), 105-123.

Rauth, I., Köppen, E., Jobst, B., \& Meinel, C. (2010). Design thinking: An educational model towards creative confidence. In T. Taura, \& Y. Nagai (Eds.), DS 66-2: Proceedings of the 1st international conference on design creativity (ICDC 2010). Glasglow: The Design Society.

Ries, E. (2011). The lean startup: How today's entrepreneurs use continuous innovation to create radically successful businesses. New York: Crown Business.

Rittel, H., \& Webber, M. (1973). Dilemmas in a general theory of planning. Policy Sciences, 4(2), 155-169.

Robelen, E. (2011). STEAM: Experts make case for adding arts to STEAM. Education Week. https://www.edweek.org/ew/articles/2011/12/01/13steam ep.h31.html

Roberts, T., Jackson, C., Mohr-Schroeder, M. J., Bush, S. B., Maiorca, C., Cavalcanti, M., ... Cremeans, C. (2018). Students' perceptions of STEM learning after participating in a summer informal learning experience. International Journal of STEM Education, 5(1), 1-14.

Rotherham, A. J., \& Willingham, D. (2009). 21st Century. Educational Leadership, 67(1), 16-21 http://cesa7ita2009.pbworks.com/f/21st+Century+Skills+ Curriculum+Teachers+Assessment.pdf.

Royalty, A., Oishi, L. N., \& Roth, B. (2013). Acting with creative confidence: developing a creative agency assessment tool. In L. Leifer, H. Platttner, \& C. Meinel (Eds.), Design Thinking Research, (pp. 79-96). Cham: Springer. https:// doi.org/10.1007/978-3-319-01303-9_6.

Scheer, A., Noweski, C., \& Meinel, C. (2012). Transforming constructivist learning into action: Design thinking in education. Design and Technology Education: An International Journal, 17(3), 8-19.

Schultz, P. W., Hernandez, P. R., Woodcock, A., Estrada, M., Chance, R. C., Aguilar, M., \& Serpe, R. T. (2011). Patching the pipeline: Reducing educational disparities in the sciences through minority training programs. Educational Evaluation and Policy Analysis, 33(1), 95-114.

Schweitzer, J., Groeger, L., \& Sobel, L. (2016). The design thinking mindset: An assessment of what we know and what we see in practice. Journal of Design, Business \& Society, 2(1), 71-94. https://doi.org/10.1386/dbs.2.1.71_1.

Shapka, J. D., \& Keating, D. P. (2003). Effects of a girls-only curriculum during adolescence: Performance, persistence, and engagement in mathematics and science. American Educational Research Journal, 40(4), 929-960.

Sousa, D. A., \& Pilecki, T. (2013). From STEM to STEAM: Using brain-compatible strategies to integrate the arts. Thousand Oaks: Corwin.

Stout, J. G., Dasgupta, N., Hunsinger, M., \& McManus, M. A. (2011). STEMing the tide: Using ingroup experts to inoculate women's self-concept in science, technology, engineering, and mathematics (STEM). Journal of Personality and Social Psychology, 100(2), 255-270. https://doi.org/10.1037/a0021385.

Tenenbaum, L. S., Anderson, M. K., Jett, M., \& Yourick, D. L. (2014). An innovative near-peer mentoring model for undergraduate and secondary students: STEM Focus. Innovative Higher Education, 39(5), 375-385. https://doi.org/10. 1007/s10755-014-9286-3.

The Cabinet Office. (2016). Kagaku gijyutsu kankei katsudoutou ni kansuru chousa, 2016 [Survey on science and technology research and activities conducted by local public or incorporated administrative entities, 2016]. https://www8.cao.go.jp/cstp/stsonota/katudocyosa/h27/innovation8.pdf

The Cabinet Office. (2018). Kagaku gijyutsu kankei katsudoutou ni kansuru chousa, 2018 [Survey on science and technology research and activities conducted by local public or incorporated administrative entities, 2018]. https://www8.cao.go.jp/cstp/stsonota/katudocyosa/h30/h30.html

The Cabinet Office (2019). Women and men in Japan, Chapter 5: Education and research fields. Tokyo: Gender Equality Bureau Cabinet Office, The Government of Japan http://www.gender.go.jp/english_contents/pr_act/ pub/pamphlet/women-and-men19/pdf/1-5.pdf. 
Trilling, B., \& Fadel, C. (2009). 21st century skills: Learning for life in our times. San Francisco: Jossey-Bass/Wiley.

van den Hurk, A., Meelissen, M., \& van Langen, A. (2019). Interventions in education to prevent STEM pipeline leakage. International Journal of Science Education, 41(2), 150-164.

Wang, M.-T., \& Degol, J. (2013). Motivational pathways to STEM career choices: Using expectancy-value perspective to understand individual and gender differences in STEM fields. Developmental Review, 33(4), 304-340. https://doi. org/10.1016/j.dr.2013.08.001.

Weber, K. (2011). Role models and informal STEM-related activities positively impact female interest in STEM. Technology and Engineering Teacher, 71(3), 18-21.

Weisberg, H., Krosnick, J. A., \& Bowen, B. D. (1996). An introduction to survey research, polling, and data analysis, (3rd ed., ). Newbury Park: Sage Publications.

Wrigley, C., \& Straker, K. (2017). Design thinking pedagogy: The educational design ladder. Innovations in Education and Teaching International, 54(4), 374-385. https://doi.org/10.1080/14703297.2015.1108214.

Yamamura, Y. (1989). Gendai Nihon no Kazoku to Kyoiku (現代日本の家族と教 育). Kyoiku Shakaigaku Kenkyu (教育社会学研究), 44, 5-27. https://doi.org/ 10.11151/eds1951.44.5.

Yata, C., Ohtani, T., \& Isobe, M. (2020). Conceptual framework of STEM based on Japanese subject principles. International Journal of STEM Education, 7(1), 1-10.

Yeager, D. S., Hanselman, P., Walton, G. M., Murray, J. S., Crosnoe, R., Muller, C., ... Dweck, C. S. (2019). A national experiment reveals where a growth mindset improves achievement. Nature, 573(7774), 364-369. https://doi.org/10.1038/ s41586-019-1466-y.

\section{Publisher's Note}

Springer Nature remains neutral with regard to jurisdictional claims in published maps and institutional affiliations.

\section{Submit your manuscript to a SpringerOpen ${ }^{\circ}$ journal and benefit from:}

- Convenient online submission

- Rigorous peer review

- Open access: articles freely available online

High visibility within the field

- Retaining the copyright to your article

Submit your next manuscript at $\boldsymbol{\nabla}$ springeropen.com 